\title{
Student Moral Character Development Throughout Civic Education
}

\author{
Tukiran Tanireja \\ Muhammadiyah University of Purwokerto \\ Indonesia \\ Email: tukiranump@gmail.com
}

\author{
Ratna Kartika Wati \\ Muhammadiyah University of Purwokerto \\ Indonesia
}

\begin{abstract}
The objective of the research is to investigate development of moral character values that are presented by civic education lecturers during learning process at Muhammadiyah University of Purwokerto. Type of the research is qualitative descriptive with all civic education lecturers of the university as respondents. Data were collected through in-depth interviews and analyzed with data reductions, data display, and conclusions drawing. The study reveals that building character of student throughout civic education requires an understanding of type character willing to be implemented. Civic learning should focus on the need of student, and the lecturer is required to acquire and use variatively various types of learning model in the education process leading to non-monotonic and non-boring learning.
\end{abstract} Keywords - moral character, civic education, students.

\section{INTRODUCTION}

Directorate General of Higher Education, Ministry of National Education, Indonesia (2010: 2) stated that character education for students is required to be designed, formulated, and operationalized throughout cultural transformation and school life. Therefore, it is necessary to build discourse and character of learning system corresponding to Unity in Diversity (Bhinneka Tunggal Ika), a national motto for representing Indonesian multicultural society.

Ministry of National Education of Indonesia launched a character educational program. The Ministry even more used it as official theme for the 2011 national education day: Educational character as pillar of national awakening. The educational character program had been inaugurated as national action since school year 2011-12 covering early childhood to higher education level, including non formal and informal education (Nuh, M., 2011:2-3)

Moral character development as effort for implementing the mandate of Pancasila and preamble of 1945 constitution of the Republic of Indonesia is based on the national reality problems developing nowadays including disorientation and disregarding fundamental values of Pancasila, degradation of ethical values in national and state life, disappearance of national cultural awareness, threat of national disintegration, and losing national independence (Main national policy of nation character development 2010 - 2025).

The development is a system to implant character values to the students consisting of knowledge, awareness or willingness, and action to implement these values to the god, himself, human beings, environment, and nation toward constructing an ideal human being (Citra, 2012).

Character supervision of students in the school can be conducted in three ways. The first, character education is performed integrally to the whole lessons. It's means character values are loaded in each learning activities facilitating application of those values during class session. The second, it is integrated in the student mentoring activities such as extra- and intra-curricular works. The last, the education is conducted throughout school management system involving the whole school citizens (Dit. PSMP Kemdiknas, 2010 cited in Marzuki and Lia Hapsari, 2015).

Organizing character education is necessary to be conducted in all educational levels, particularly in the basic level as the fundamental foundation for growth and development of Indonesian young generation. Deep understanding of practitioners to concept of the character education plays a center role for succeeding the learning in each educational unit. Nevertheless, as the educational character is integrated in curriculum study for almost all level education, teacher's understanding and acquisition of educational character concept is required to be reviewed (Zuluuraini, 2012).

According to Budimansyah (2015:9), required civic character in the organization of learning activities is to achieve national educational goals including development of student to become a religious human being, beliefs to god, has a good attitude, healthy, knowledgeable, competent, creative, independent, and democratic and responsible citizen.

Armawi (2014:508) stated that development of nationalism in the higher educational level within current educational system is to foster a sense of nationalism, and it can be implemented throughout Pancasila moral 
education. Because the development student's character is not an easy task, there are always problems concerning methods of civic education lecturers to develop character values of their students throughout civic learning. The study presents various character values developed by the lecture during learning sessions.

\section{RESEARCH METHODOLOGY}

The study was conducted using a qualitative descriptive data analysis. The method concerns about status, attitude, group opinion, device, condition, and procedure of a thought system or occasion to construct a description systematically and analytically that can be used to solve an actual problem in present time.

The study was performed at Muhammadiyah University of Purwokerto during April to September 2016. The respondents were all civic education lecturers of the university consisting nine persons. Data were collected through open and in-depth interviews meaning the respondent knows when being interviewed and aims of interviews. Open interviews mean the respondents are free to answer in any direction based on their works of character development during civic education classes.

The qualitative data analysis was conducted based on following diagram:

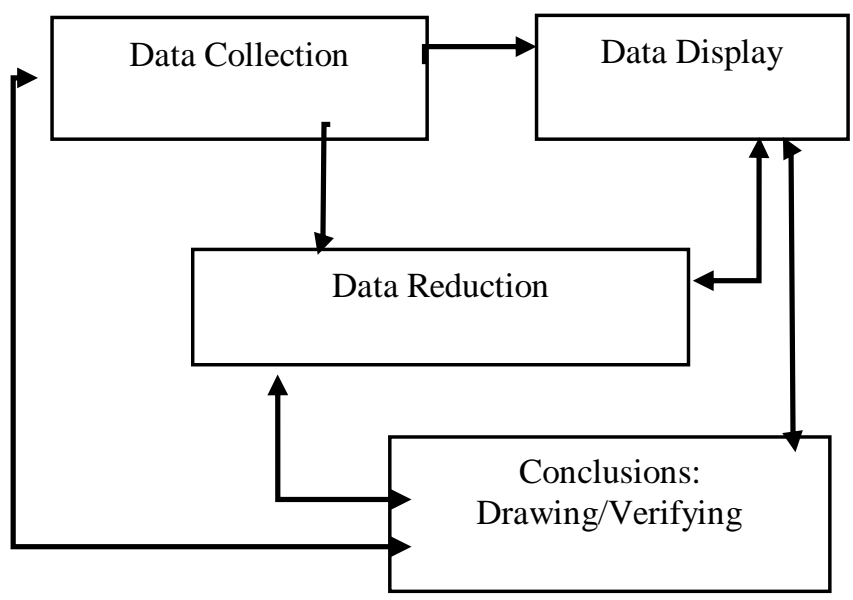

The data analysis consists of data reductions, data display, and conclusion and verification. When data reduction analysis was conducted, the researcher synthesizes, chooses, and focuses on primary sources involving the searching for themes and patterns across the data set. Then they were displayed with narrative texts facilitating better understanding about what things happen and planning subsequent works. The data analysis steps were terminated with a deduction and results verification.

\section{RESULTS AND DISCUSSION}

The study focuses on developing and implanting eighteen moral characters to students involving religious attitude, honest, tolerance, discipline, hard work, creative, independent, democratic, curiosity, nationalism, nation spirit, appreciate an achievement, friendly attitudes, preference for the peace, love of reading, social care, environmental care, and responsibility.

The religious attitude can be developed throughout religious belief exampled by the lecturer. Implementation of honest character is commenced from the student itself by working alone during an evaluation and doing class tasks honestly. To develop a social tolerance with awareness to the differences, an introduction to the diversity is required. Development of self-discipline is adapted with a flexible commitment considering human values.

Hard work character is developed by motivating and training the student to do multiple and various class tasks leading them to a consistent works. Reward and punishment motivation can be applied to the student concerning to seriousness of their works. Creative character leads the student to become a tough and persistent human keeping performance to create new innovation. The character also drives the student to see a challenge as a chance and to go beyond satisfaction leading continuous development. Independent character can be developed throughout giving multiple class tasks and continuous evaluations leading the student works independently. While democratic character is developed by giving deep understanding to the student about the right to freedom of opinion and expression without imposition of the will.

The curiosity can be developed by giving the student a chance to ask question during learning process. When the learning process terminates without single question, the lecturer can stimulate the student to ask by giving a reward. To develop nationalism, the lecturers can give an example to the student how to act emphasizing national interests and give suggestion for prioritizing national objectives. To develop a nation spirit, an understanding about effort of patriots for reaching national independence by risking their lives is required to be disseminated to the student.

Character of appreciation to achievement can be developed throughout funding stimulation to service society and respecting intellectual property rights. Friendly attitude is developed by raising awareness of the student about the right to freedom of opinion. However, it should have realized that the expression of opinion is conducted politely without hurting other peoples. Development of peaceful character can be conducted by establishing communication and hospitality in society and avoiding dissemination of provocation issues.

Love reading character is developed by giving awareness to importance of reading books to gain knowledge. To improve reading interest, it is necessary to understand reading aim, at least reading for opening minds. Social care development can be conducted by implementing a sincere attitude, giving unconditionally, and avoiding self-praise. To develop environmental care character to the student, it is necessary to provide an 
understanding about importance of environmental factors for human living. Finally, the responsibility character can be developed by giving the student trust. The development of those characters is required to be conducted regularly and continuously.

\section{CONCLUSION}

The main factor in character implementation is excellence attitude examples by the lecturer leading to direct character learning for the student. Effort to implement moral characters throughout civic education learning is not an easy job. Various methods and ways are required to be adapted with type of character willing to implement to the student. Hopefully, the civic education lecturers can acquire various learning methods and applied variatively to non-monotonic and non-boring,

\section{REFERENCES}

Armawi, A., (2014). Aktualisasi Nasionalisma dalam Pembangunan Karakter Mahasiswa, PKn Progresif Jurnal Pemikiran dan Penelitian Kewarganegaraan, Vol. 2. No. 2 Juli 2014 Prodi PPKn FKIP Universitas Sebelas Maret.

Budimansyah, D., (2015). Nilai-nilai Karakter Mata Kuliah Umu (MKU) bagi Mahasiswa, Aktualisasi Karakter Kewarganegaraan dalam Membangun Smart and Good Citizen di Perguruan Tingggi, PKn Progresif Jurnal Pemikiran dan Penelitian Kewarganegaraan, Vol. 10. No. 1 Juni 2015 Prodi PPKn FKIP Universitas Sebelas Maret.

Citra, Y., (2015). Pelaksanaan Pendidikan Karakter dalam Pembelajaran, Jurnal Ilmiah Pendidikan Khusus, Volume 1 Nomor 1. Januari 2012. http:// ejournal.unp.ac.id/index.php/jupekhu.

Direktorat Jenderal Pendidikan Tinggi Kementerian Pendidikan Nasional, (2010) Sarasehan Nasional Pendidikan Karakter, Jakarta: Direktorat Jenderal Pendidikan Tinggi Kementerian Pendidikan Nasional Direktorat Jenderal Pendidikan Tinggi Kementerian Pendidikan Nasional.

Marzuki dan Lysa Hapsari, (2015). Pembentukan Karakter Siswa melalui Kegiatan Kepramukaan di MAN 1 Yogyakarta, Jurnal Pendidikan Karakter, Tahun V, Nomor 2, Oktober 2015.Fakultas Ilmu Sosial Universitas Negeri Yogyakarta

Nuh, M., (2011). Pendidikan Karakter sebagai Pilar Kebangkitan Bangsa, Pidato Hari Pendidikan Nasional 2 Mei 2011

Zuluuraini, (2012). Pendidikan Karakter: Konsep, Implementasi Dan Pengembangannya di Sekolah Dasar di Kota Palu, Jurnal DIKDAS, No.1, Vol.1, September 2012, 